\title{
Abbreviations and Other Conventions
}

For full citations, see the bibliography.

EIr Encyclopaedia Iranica

IS Iranian Studies

LHP Edward Granville Browne, $A$ Literary History of Persia

$M D \quad$ Ali-Akbar Dehkhodā, Maqãlāt-e Dehkhodā

RMM Revue du monde musulman

SE Sur-e Esräfil

$S E$ was published from May 1907 to March 1909. Its issues appeared in two series: "year I," which actually spanned two calendar years (1907-8), even by the Persian solar and Islamic lunar reckoning, and "year 2," which was in 1909. Two of the first publications of Dehkhodā’s Charand-o Parand as a separate work (in Sa'id Nafisi's anthology of 1951, and the Ketāb-e Jibi paperback of 1962) use the Persian term for "series" instead of "year," a practice adopted here. Series I comprised weekly issues numbered I to 32 (though $S E$ skipped 9 and Io; see our headnote for no. II). Series 2 comprised just three issues, each several weeks apart, numbered I to 3 . In this 
book, references to particular Charand-o Parand columns cite the issue number of the $S E$ in which they were published. Since almost all belong to series I, we omit the series number for series I and add it just for series 2. In labeling the columns we give the series and issue number and the date of publication in the Gregorian calendar.

Editorials and articles in $S E$ other than those under the heading Charand-o Parand are referred to by issue number, Persian title (if present), and page range.

Dates cited from the text or masthead of $S E$ and contemporary periodicals are in the Islamic lunar (Hejri-e qamari) calendar and are followed (unless the month is named) by the abbreviation $\mathrm{Hq}$ and the Gregorian equivalent. Publication dates of Persian works in the bibliography (except $S E$ ) are in the Islamic solar or Iranian Shāhanshāhi calendar, followed by the Gregorian equivalent.

Transliteration of Persian names and terms (where there is no conventional English form) follows a common Persianist system, using $a, e, o$ for the "short" vowels and $\bar{a}, i, u$ for the "long" vowels and usually omitting initial 'ayn. A few Arabic words and phrases used in an Arabic or general Islamic context are transcribed in accordance with the Arabist convention, with $a, i, u$ for the short vowels and $\bar{a}, \bar{i}, \bar{u}$ for the long vowels. Diacritics to distinguish Arabic consonants (on $d, h, s, t, z$ ) are not used, except in a very few cases where orthographic precision is essential to the meaning.

Unless otherwise indicated, all translations are ours. Headings and subheads within brackets have been supplied. 